水文・水資源学会誌 J. Japan Soc. Hydrol \& Water Resour. Vol. 11, No. 6 (1998) pp. 623-632

\title{
シリーズ「乾燥地の潅泩農業と水環境」
}

\section{潅溉農地における蒸発散と流域の気象・水資源： アラル海流域の潅湛農地の熱・水収支と広域水収支}

\author{
京都大学農学研究科 大手信人 * 小杉賢一朗**
}

\section{I 、はじめに}

ソビエト連邦の崩噮以後，旧ソ連各国での環境問 題が西㑡に伝わるようになり，当時その象徽的な問 題の一つとしてアラル海の縮小と周辺の環境悪化が 報道された. アラル海の水量滅少は, 流入河川であ るアムダリア川とシルダリア川の沿岸に1950年代か ら開かれた広大な潅濞農業地带での強度の水消費が 大きな原因であると考えられている(本シリーズ, 筒 井(1998)による解説参照). 本稿の目的は, 乾燥地に おける潅溉農業が水環境に与える影響のうち, 上記 のように最も構造的な問題を生じ易い蒸発散損失の メカニズムとその把握手法を解説することにある.

筆者らは1992年から1994年にかけて，アラル海と 同様な問題の発生が危惧されているカザフスタン共 和国内のバルハシ湖流域で, 数種の土地利用条件に おける熟・水収支観測を含む調查を行った(小杉・ 福䳆，1994; Kosugi et al., 1995)。ここではまず，現 地調査で得られた乾燥地における潅袮農地の熱・水 収支特性を解説し，それらの知見を踏まえた上で大 気陸面水收支法を用い,アムダリア・シルダリア川 流域からアラル海にいたる流域(以下，アラル海流域 と呼ぶ)全体の蒸発散量推定を行う。さらに, 得ら れた流域水収支とアラル海の水量隇少に関し考察し た過程 (Ohte et al., 1996)を解説する，なお，前半の 熱・水収支観湘に関する解説は小杉, 後半の広域水 収支に関する解説は大手が分担して執筆に当たった。

II. 潅溉農業による地表面熱・水収支特性の変化

$$
\text { ここでは, 潅袮農地やその周辺地域における地表 }
$$

面熱・水収支の観測結果を紹介し，その特性を決め ている土壇, 地下水位, 土地利用形態, 植物の生理 特性等の要因について解説する.

\section{1. 調查地の概要}

カザフスタン共和国のアルマティからバルハシ湖 にかけての乾燥地帯においては, イリ川より大量の 取水が行われ, 大規模潅溉農業が営まれている (図一-1).1984年におけるこの地域の潅溉面積は $3,700 \mathrm{~km}^{2}$ であり年々増加している(福鴧, 1993)こと から，バルハシ湖においてもアラル海同粎の問題が 引き起こされることが危惧されている。

観測は図ー1に示したイリ川沿線の潅溉農場(べ レケ・ソホーズ)で行った．図一 2 は農場に近接する バカナス気象観測所で計測された1991年の月別雨量 と平均気温である，年降水量は $114.3 \mathrm{~mm}$ と少なく， 年平均気温は9.1ㄷである。この農場は1979年に開 設され，潅溉地面積は5, 172ha，うち水田が2, 100 haであり，水稲，大麦，アルファルファを主要作 物とした輪作が行われている(福嶌，1993）。農場開 設前の植生はアカザ科の高木である黒サクサウール (Haloxylon aphyllum)を主とする潅木原と考えられる (小林ら，1994)。農場内には素堀の潅貺水路が張り 巡らされており，5～9月の潅溉期には水田に水が 張られ，大麦やアルファルファの㚼でも地下水位が かなり高くなっている，1993年の計画用水量は, 約 1 億 5,000 万 $\mathrm{m}^{3}$ (約 3,000 mに 1994).

観測は，6月下旬から 8 月にかけて，農場内の裸 地，農場から $10 \mathrm{~km}$ 離れた地点にあるサクサウールの 


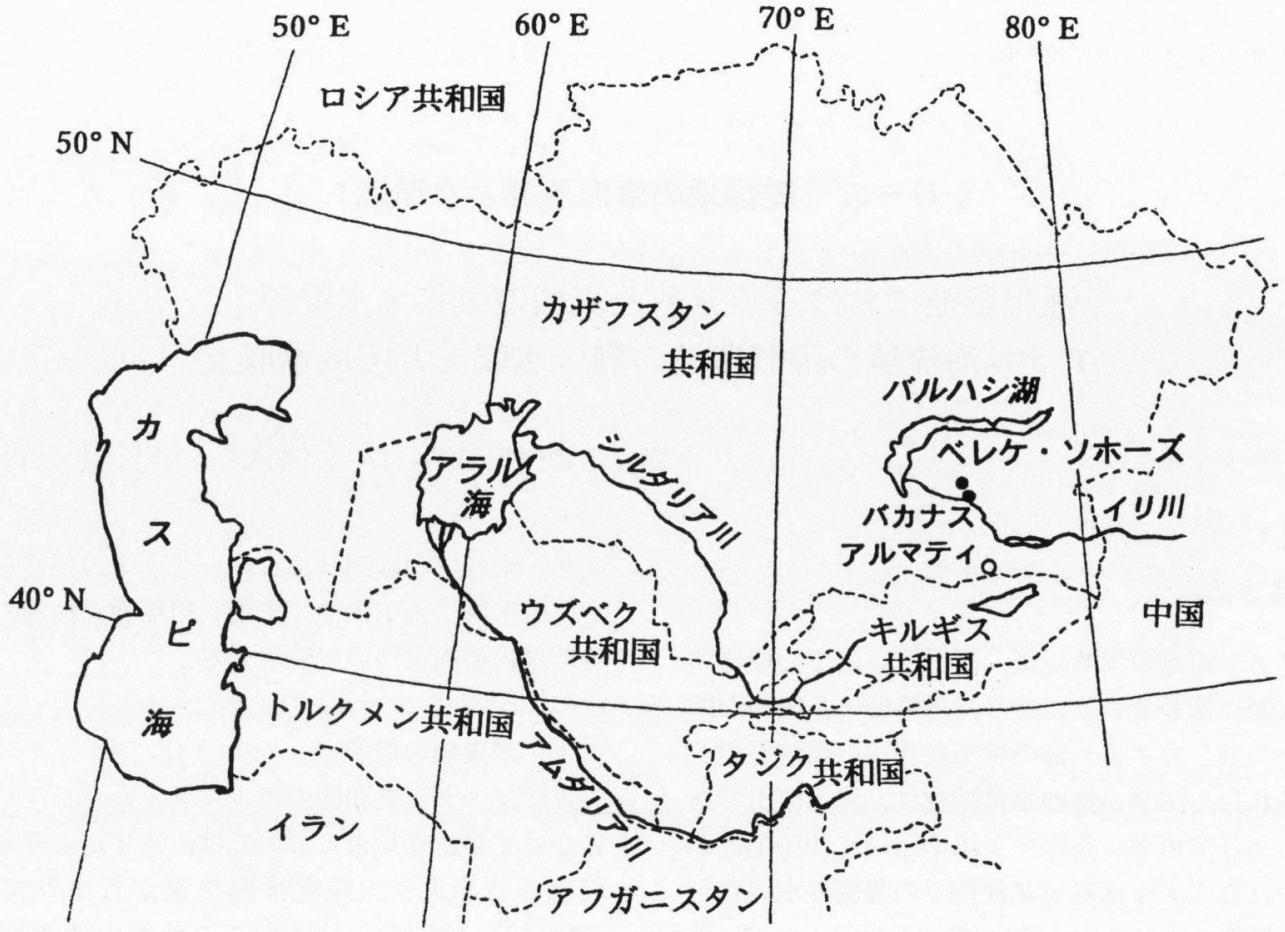

図ー1 観測を行った潅溉農場の位置(小杉・福嶌, 1994)

Location of the irrigated farm

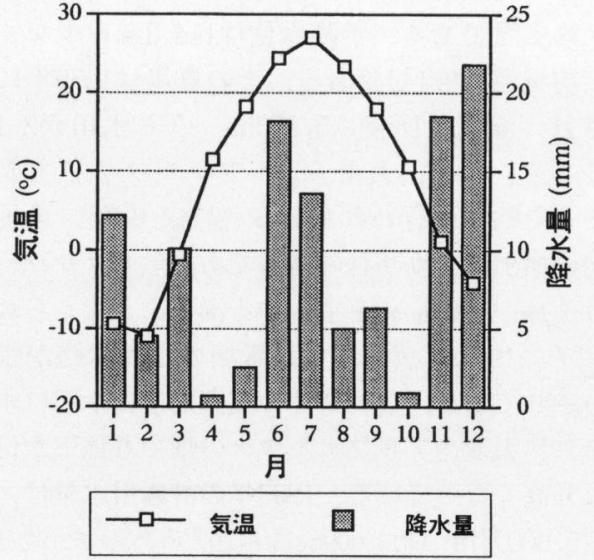

図一２潅溉農場付近の1991年の月別降水量と月平 均気温(小杉・福嶌, 1994)

Monthly precipitation and air temperature in the vicinity of the irrigated farm in 1991

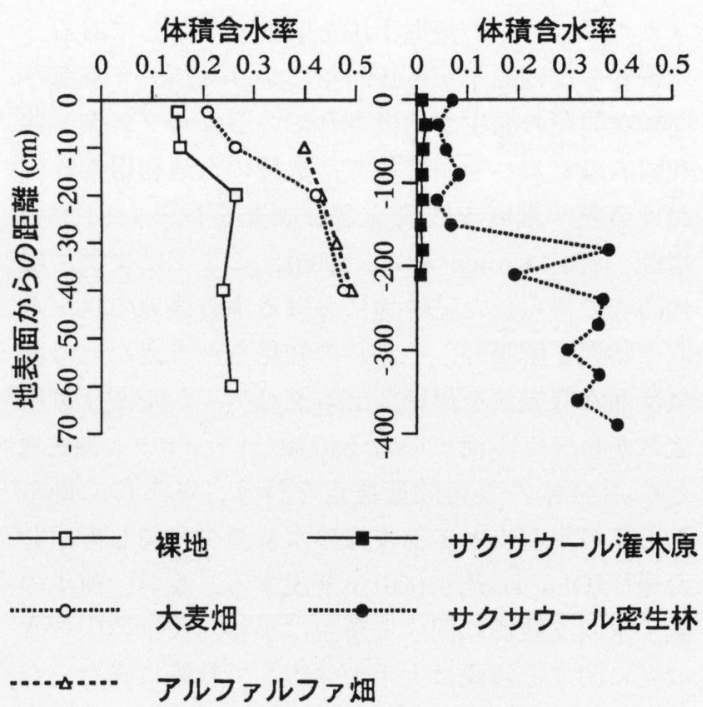

図－３ 土壤水分プロファイル(Kosugi et al., 1995) Soil moisture content profile 
潅木原, 農場内にあるサクサウールの密生林, 大麦 畑，アルファルファ畑，および水田に揖いて行った。 図一 3 は，各観測地点の土䁃体積含水率の鉛直プロ ファイルを示したものである. 裸地では表層近くで も15\%程度の含水率を持つが, 最表層部分には含水 率が極めて低い層の発達が認められた. サクサウー ルの密生林 (最高樹高 $5.1 \mathrm{~m}$, 葉面積指数 0.49 , 地下水 位 $4 \mathrm{~m}$ ) は海木原 (最高樹高 $2.2 \mathrm{~m}$, 葉面積指数 0.15 , 地 下水位 $3 \mathrm{~m}$ ) に比べて含水率が高くなっていた，大麦 とアルファルファの畑では，地下水位がそれぞれ $80,40 \mathrm{~cm}$ に存在し, 草丈は共に $60 \sim 70 \mathrm{~cm}$ でった. 水田での湛水深は約 $15 \mathrm{~cm}$ であり，観測を行った 7 月 2 日には稲が水面上 $35 \mathrm{~cm}$ まで生育していた。

\section{2. 地表面エネルギー収支}

地表面におけるエネルギー収支は次式で表される。

$$
R_{n}=G+H+l E
$$

(1)式は，地表面での短波と長波の収支として求めら れる純放射量 $\left(R_{n}\right)$ が, 地中伝導熱量 $(G)$, 顕熱 ラックス $(H)$ ，および潜熱フラックス $(l E)$ に分配さ れることを示している．ただし，lは水の気化潜熱， $E$ は蒸発散量である. 実際の観測では，放射収支計 および超音波風速温度計を用いて $R_{n}$ と $H$ を計測し， $G$ は地温と土壤含水率の鉛直分布より算定した。 そ の上で，(1)式を用いてIEを算出した，なお，水田 ではHの直接計測は行っておらず，エネルギー収支 式とバルク式(バルク輸送係数 0.005 , 蒸発効率 0.8$)$ を 組み合わせることにより(竹内・近藤, 1981) H, lE を推定した。

観測結果から得られた各地点のエネルギー収支を 图一 4, 表一 1 にまとめた。裸地では純放射量のほ とんどが顕熱フラックスとして消費され，潜熱フ ラックスは1日を通してゼロに近い值をとった (図一 $4 \mathrm{a})$. 顥熟フラックス $H$ と潜熱フラックス $l E$ の比(ボーエン比)は地表面に扮けるエネルギー交換 過程を特徴づける重要なパラメータであるが，その 日平均値は 18 と大きくなった(表一1). サクサウー ルの潅木原でも，純放射量の $90 \%$ 近くが顕熱フラッ クスとして消費された(表一1). 夜明け後, 潜熱つ ラックスは顕熱フラックスと同様に上昇するが，10 時以降は隇少に転じた (図一 $4 \mathrm{~b})$. サクサウールの 密生林では，8～10時にかけては純放射量の多くが 蒸発散に用いられていたのに対し，16時以降は顥熱 フラックスが純放射量の大半を占めていた(四一 4 c).そして, 潜熱フラックスの日変化は午前中に

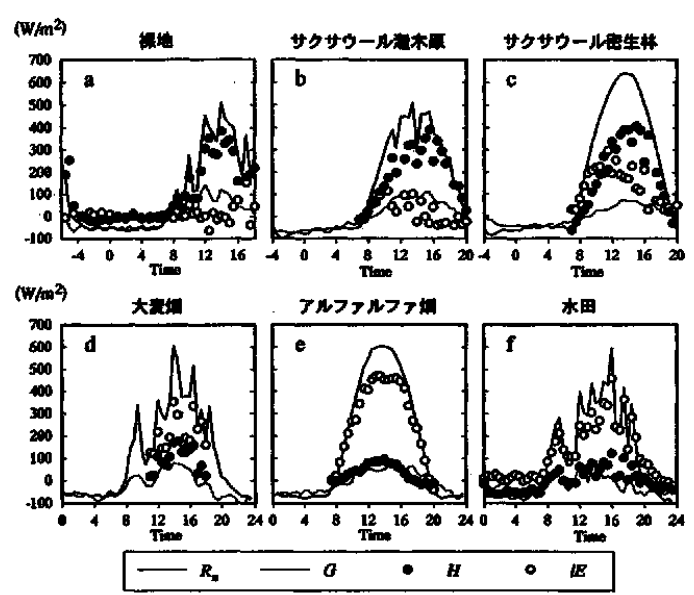

図一 4 純放射量 $R_{n}$, 地中伝道熱是 $G$ ，顕熱フラッ クス $H$, 潜熱 フラックス $l E の$ 日变化 $(\mathrm{Ko}-$ sugi et al " 1995)

Diurnal changes of net radiation, $R_{n}$, soil heat flux, $G$, sensible heat flux, $H$, and latent heat flux, $l E$

表一 1 純放射量 $R_{n}$ ，地中伝導熱量 $G$ ，顕熱フラッ クス $H$, 潜熱フラックス $l E$, 蒸発散目 $E$ の 日糟算値とボーエン比 $H / l E$ (Kosugi et al. 1995)

Daily accumulated values of net radiation, $R_{n}$ soil heat flux, $G$, sensible heat flux, $H$, latent heat flux, $l E$, and evapotranspiration, $E$, and Bowen ratio, $H / l E$

\begin{tabular}{|c|c|c|c|c|c|c|}
\hline 涀湿植所 & $\begin{array}{c}\boldsymbol{R}_{\mathrm{n}} \\
\mathrm{MJ} / \mathrm{m}^{2}\end{array}$ & $\begin{array}{c}G \\
\mathrm{MJ} / \mathrm{m}^{2}\end{array}$ & $\begin{array}{c}H \\
\mathrm{MJ} / \mathrm{m}^{2}\end{array}$ & $\begin{array}{c}I E \\
\mathrm{M} J / \mathrm{m}^{2}\end{array}$ & $\begin{array}{c}E \\
\mathrm{~mm} / \mathbf{d}^{\mathbf{C}}\end{array}$ & $H / / E$ \\
\hline 壦地 & 8.9 & -0.1 & 8.5 & 0.5 & 0.2 & 17.95 \\
\hline サクサウール湤木医 & 10.7 & 0.2 & 9.3 & 1.3 & 0.5 & 7.33 \\
\hline サクサウール密生林 & 15.2 & 0.1 & 8.6 & 6.5 & 2.6 & 1.32 \\
\hline 大责㛎 & 9.7 & -2.4 & 3.8 & 8.3 & 3.4 & 0.46 \\
\hline アルファルファ㚼 & 13.4 & -0.6 & 1.6 & 12.4 & 5.1 & 0.13 \\
\hline 水田 & 8.9 & -1.5 & 0.01 & 10.3 & 4.2 & 0.001 \\
\hline
\end{tabular}

ピークを持つ非対称な曲線となった、日蒸発散量は $2.6 \mathrm{~mm}$ 潅木原に比べて大きくなった(表一1).

大麦畑では，日中は常に潜熱フラックスが顥熱フ ラックスを上回り(図一 4d), ボーエン比の日平肉 値は 1 より小さなった(表一1)。アルファルファ 㚼では日中に潜熱フラックスが顕熱フラックスを大 きく上回った(図一 $4 \mathrm{e})$ ，サクサウールの潅木原や 密生林(图一 $4 \mathrm{~b}, \mathrm{c}$ ) と異なり, 潜熱フラックスの日 変化が純放射量と同時刻にピークを持つ左右対称な 曲線を描いていることがわかる，日蒸発散量は5.1 m的に達した(衰一1). 水田でも純放射量のほとんど 
が潜熱フラックスとして消費された(图一 $4 \mathrm{f})$. 顕熱 フラックスの日積算値が小さいことから, ポーエン 比は非常に小さくなった(舞ー1).

\section{3. 地表面エネルギー交換過程を特徽つける要因}

\section{1 )土境，地下水位および土地利用形態}

地下水位一定の条件下での裸地面蒸発過程では, 液状水の上向きフラックスに土壤の不飽和透水係数 によって決まる上限值が存在する(Jury et al., 1991). これは, 土壤表面の乾燥が, ポテンシャル勾配の增 加によって地下水を吸引する力を增加させる効果と, 不飽和透水係数を急激に減少させる効果を同時に持 つからである.この液状水フラックスの上限值は地 下水位の低下に伴って小さくなり，それによって土 埕面蒸発量は娍少してしまう。観測を行った裸地に おいて，最表層以外の土層の含水率がそれ汪ど低く ない(图一3)にも関わらず替熱フラックスが極めて 小さくなった(図一 4a)のは，このような土壤物理 的機構が反映された結果と考えられる。一方で植生 が存在する場合は，根系による土壤水分吸収によっ て土壤の乾嬠がより梁層まで進み，图一ろに示した サクサウール潅木原や密生林のような土壤水分プロ ファイルが形成される，言い換えれば，乾嬠地では， 植生が存在すると, 蒸散作用によって水の消費量が 增えることになる(表一 1 参照)．根系による水分吸 収がどの程度の含水率まで行われるかは，植物と土 壤の水分特性によって決まっている.

既速したと㧍り，サクサウールの密生林は潅溉農 場内にあるにもかかわらず，そこでの地下水位は潅 木原の地下水位よりも深い位置に存在していた。 従って, 両林分におけるサクサウールの生育度の違 い,さらには蒸発散量の違い(図一 $4 \mathrm{~b}, \mathrm{c})$ は, 潅溉 の影響によってもたらされたというよりも，むしろ， 元来の自然条件の違いが原因であると考える方が妥 当であろう。密生林地の土壤は潅木原の土壤に比心゙ てより細かな土性を示しており，この土性の違いが 地表面に㧍けるエネルギー交換過程の違いをもたら した可能性が高い，なぜなら，細かな土性を持つ土 埕は不飽和状態での透水係数が大きい(Jury et al., 1991)ため, 根域への地下水面からの水分供給がよ り容易に行われると考えられるからである.

農場開設前の植生と考えられるサクサウールの潅 木原や密生林に比べ，大麦畑やアルファルファ畑の 潜熱フラックスは大きい(表一1)。この原因として, 而㚼地における高い地下水位を指摘することができ
る．地下水面が $40 \mathrm{~cm}$ 位置にあるアルファルファ畑 では，大麦畑(地下水位 $80 \mathrm{~cm}$ )よりも潜熱フラックス が大きく，水田に近いエネルギー収支を示した (図一 4). 㚼地土壤における蒸発散に伴う上向きの 水分移動は塩類集積の問題を引き起こす(Jury et al., 1991)が, この農場では, 水田稲作 ( 4 年輪作中の 2 作)によるリーチングで除塩が行われることもあり， これまでのところ土裹の極端な塩性化は起こってい ない(舟川ら，1996)。しかしながら，将来的な潅溉 地面積の堌加がリーチング用水の確保を難しくする 可能性があり，固場用排水施設の改良や水管理シス テムの再編(Watanabe, 1995)などで㚼地の地下水位 を低く押さえる工夫をする必要があろう。

\section{2)植物の生理特性}

乾燥地に適応した在来種と潅溉㖘地化で導入され た作物との間の生理特性の違いも, 地表面エネル ギー交換過程を变化させる大きな要因と考えられる。 植物は気孔の開閉によって, 大気との間の $\mathrm{CO}_{2} や \mathrm{H}_{2} \mathrm{O}$ の交換過程を制御している。このため植生の影響を 考虑した蒸発散量のモデル化においては，植生群落 全体を 1 つの菜(Big-Leaf) とみなし，気孔による制 御を群落抵抗 $r_{c}$ 表現した次式が広く用いられてい る(小杉, 1995).

$$
l E=\frac{\rho C_{p}}{\gamma\left(r_{a}+r_{c}\right)}\left(e_{s}\left(T_{0}\right)-e\right)
$$

ただし, $\rho$ : 空気の密度, $C_{p}$ : 空気の定圧比熱, $\gamma$ : 乾湿計定数, $e$ : ある測定高における水蒸気圧, $T_{0}$ : 地表面温度, $e_{s}\left(T_{0}\right):$ 気温 $T_{0}$ における飽和水蒸 気圧, $r_{a}$ : 空気力学的抵抗である. 群落抵抗 $r_{c}$ の逆 数である群落コンタクタンス $g$ 怆，気孔開度を表す パラメータであり，その值が大きいほど，植物が気 孔を大きく開けて大気とのガス交換を活発に行って いることを示している． gcの大きさは，気孔の数や 大きさといった植物㑡の要因，さらに日射量と相関 をもつ光合成有効放射量PAR, 空気の乾嬠度を表す 大気飽差 $D\left(=e_{s}(T)-e, T\right.$ は $e$ 同じ測定高に扔ける気 温), 気温, 土壤水分量などの環境要因により決ま ることが知られている(島田，1992)．ここでは，潅 溉農地化に伴う変化を考察するために，サクサウー ルの潅木原, 密生林, およびァルファルファ畑につ いて，実測データから求めた各変数を(2)式に代入す ることによって $g_{\mathrm{c}}$ の算定を行い，日射量から算定し たPARや飽差 $D$ との対応関係を調べた(图一5，6).

サクサウールの潅木原と密生林の群落コンダクタ ンスは，共に飽差と明瞭な負の相関を示した(図一 


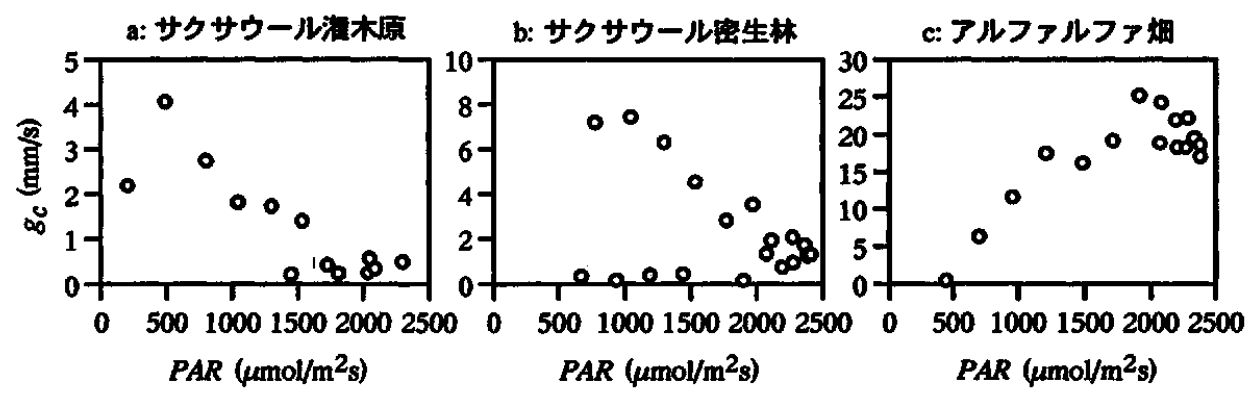

図一 5 群落コンダクタンス $g_{c}$ と光合成有効放射量PARの関係 (Kosugi et al., 1995)

Relationship between canopy conductance, $g_{c}$, and photosynthetically active radiation, PAR
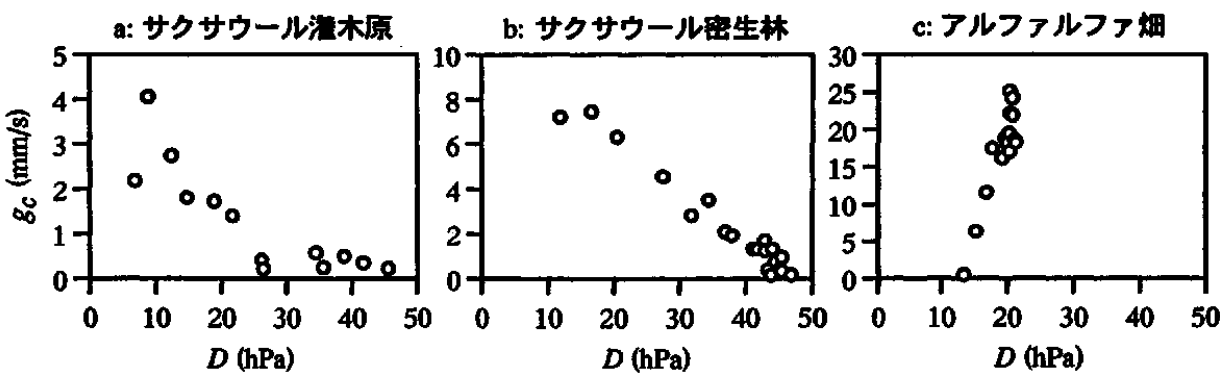

図一6 群落コンダクタンス $g_{c}$ と大気飽差 $D$ の関係 (Kosugi et al., 1995)

Relationship between canopy conductance, $g_{c}$, and air saturation deficit, $D$

6).そして飽差の小さな午前中には大きな值をと り，飽差の大きな午後に小さくなるため，光合成有 効放射量(日射量)との相関ではループを描いた (図一5).これは，飽差の小さな午前中に気孔を開 けて光合成を行い，飽差の大きな午後には気孔を閉 じることで体内水分の欠損を防いでいるためだと考 えられる，図一 $4 \mathrm{~b}$ ，cにおいて潜熱フラックスが 午前中にピークを持つ非対称な日変化を示したのは, このような群落コンダクタンスの日変化を反映した 結果であるといえる．また図一6からは，飽差の增 加に伴う群落コンダクタンスの隇少は，潅木原にお いてより小さな飽差から起きていることがわかる. 土壤水分条件の撖しい潅木原では, 密生林に比べて 乾燥に対してょり敏感に気孔を閉じる必要があるた めと考えられる。

一方アルファルファ畑の群落コンダクタンスは, 光合成有効放射量の增加に伴って增加した(图一5) が，飽差との間に明暸な相関は見られなかった (图一6)。これは，アルファルファが飽差の增加に 合わせて気孔を閉じるといった耐乾性を持たず，単 に光合成有効放射量 (日射量)の増加に合わせて気孔
を大きく開き光合成を活発に行うためだと考えられ る。この結果, アルファルファ畑では，潜熱フラッ クスが日射量や純放射量に良く似た日変化を示し (図一 $4 \mathrm{e}$ )，その日積算值も大きくなったといえる (表一 1).このように，一般に作物として導入され る植物には，在来種のような耐乾性を持たないもの が多いため，その生育を維持するために多くの水を 供給する必要が生ずる.

\section{III. アラル海流域の蒸発散量推定}

アムダリア川，シルダリア川の流域面積を足すと 100 万 $\mathrm{km}^{2}$ を超える．アラル海の水资源問題を流域水 収支的に検討するならば，こうした広域の情報が扱 え，且つ空間的な分布をある程度フォローできる手 法が要求される。客観解析が施された大気物理デー 夕を用いる大気陸面水収支法はそのための有力な方 法のうちの一つである.

\section{1. 大気水収支法}

大気水収支法は，対象とする領域上空の大気中に おける水の出入りを気象データから算出するという 
コンセプトに基づく．大気と陸面との相互作用は降 水と蒸発散であるが, 地上での降水量が既知であれ ば，収支からその領域の蒸発散量を推定することが できる。近年, 客観解析データの整備が進み,これ を用いた大気水収支法による広域の蒸発散量推定は 次第に信頼性を増している(Oki et al.,1995). 対象 とする領域上空の水収支は次のように表現される。

$$
\partial W / \partial t=-\nabla_{H} \cdot Q+(E-P)
$$

ここで, $W, Q, E, P$, はそれぞれ可降水量(上空 大気中に含まれる水蒸気貯留量)，鉛直方向に積算さ れた水平二次元方向の水蒸気フラックス, 蒸発散量, 降水量を示す. $\nabla_{H}$ は水平方向の発散を示し, $Q$ は 緯度・経度方向のフラックスの合成ベクトルである. $\partial W / \partial t$ と $\nabla_{H} Q$ は, 上空大気中の 3 次元格子状に得 られる客観解析デー夕(気温, 水蒸気圧, 風速, 風向) を用いて算出することができる。このため，降水量 のデータが得られれば任意の領域の蒸発散量を推定 することができる．この方法は，大気条件と降水量 の両方データが揃えば，月単位，日単位程度の短期 の水収支計算にも有効である。 また，大気条件と降 水量のデータが得られる範囲では, 計算領域を任意 に設定することができ, 従来の陸面での水収支法と 異なり集水域に縛られないという利点もある。

一方，その領域の陸面における水収支は以下のよ うに表現できる。

$$
\partial S / \partial t=-\nabla_{H} \cdot R_{o}-(E-P)
$$

$S$ は領域の貯留量, $R_{o}$ は流出量である。この場合貯 留量には土䁃水分や地下水での貯留ばかりでなく積 雪による眝留も含まれる， $R_{0}$ は正味の流出量を意味 し, 周りからの流入量を周りへの流出量から差し引 いて求められる。(3)式と(4)式を組み合わせることで 大気一陸面水収支式が得られる.

$$
\begin{aligned}
\partial S / \partial t+\nabla_{H} \cdot R_{o} & =-\partial W / \partial t-\nabla_{H} \cdot Q \\
& =P-E
\end{aligned}
$$

対象としたアラル海流域は，東西にはアラル海の 西岸域からバルハシ湖の東岸域まで $\left(55^{\circ} \mathrm{E}-80^{\circ} \mathrm{E}\right)$, 南北にはトルクメニスタンの南端からカザフスタン 平原の中央部 $\left(35^{\circ} \mathrm{N}-50^{\circ} \mathrm{N}\right)$ に広がる(図一7)。アラ ル海は流出河川がなく，この特徴によって上の水収 支計算は単純化されることになる。つまり，

$$
\begin{aligned}
\partial S / \partial t & =-\partial W / \partial t-\nabla_{H} \cdot Q \\
& =P-E
\end{aligned}
$$

となる。この関係式は，流域眝留量の時間変化は正 味の水蒸気収束量に等しくなることを示している.

「アラル海が干上がる」(Micklin, 1988)という現

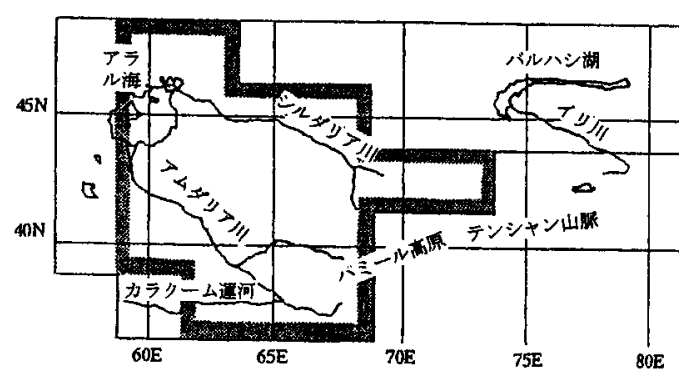

図一7 解析対象地域とアラル海流域(Ohte et al. 1996)

太線で囲われた部分は大気水収支法を適用 した時のアラル海流域の範囲である。

Study Area

The portion indicated by Sea basin defined for the atmospheric water balance analysis.

象は，とりもなおさず流域貯留量が年タ減少してい ることを示しており，広く報道されている湖水の減 少過程は上記のような大気陸面水収支法による検討 によってより定量的にメカニズムが明らかになるは ずである。このため, 対象とするアラル海流域を $2.5^{\circ} \times 2.5^{\circ}$ のグリッドでカバーし，この手法を適用 した. 大気水収支の計算を行った領域は，アラル海 流域に加えてイリ川からバルハシ湖に至る流域を含 む41個のグリッドからなる.本解析ではこのうち 図一 7 中に枠付きで示した19個のグリッドでカバー される範囲をアラル海流域と定義した。

\section{2. 大気物理量・降水量データ}

水蒸気収束量を計算するために用いたデータは， ヨーロッパ中期気象予測センターによってリリース されている 4 次元同化による客観解析データである. 降水量データとしてはLegates and Willmott(1990) によって編集された気候値を用いた。このデータ セットは世界24,635個所の地上雨量計観測值と 2,223 地点の海上雨量推定值をもとに, $0.5 \times 0.5$ 度 のグリッド上に内挿処理されたものである.

\section{NOAA/GVIデータを用いた土地利用の分類}

対象地域の景観生態学的植生分類図をNOAAか ら配布されているGVI(Global Vegetation Index: 全 球植生指標)データを用いて作製した。1988年 3 月 4 日から10月30日までの35枚の週間コンポジット データを用いクラスタ分類を行い，現地調查による グランドトルースを用いて 5 タイプの植生地域を同 
定した.

\section{4. 年間蒸発散量の空間分布}

対象地域の年降水量, 水蒸気収束量, 蒸発散量の 空間分布を図ー8〜10に示す. 純水蒸気収束量の計 算值は1989〜1992年の平均值である。アムダリア． シルダリア川の源流，あるいはイリ川の源流域は, パミール高原，テンシャン山脈に連なる森林地带で ある。この地域では比較的年降水量が多く, $400 \mathrm{~mm}$ を超すところもあるが，アラル海流域を含む平原部 では, 150 250mmである. 純水蒸気収束量は山岳地 域で正の值を示し，流出が生じていることがわかる， これに対し，カザフスタン・ウズベキスタン・トル クメニスタンに広がるアラル海流域中下流部では, ほとんどの範囲で年間の純水蒸気収束量はマイナス の値をとるという対比が明らかである。つまり, 降 水量の多い山岳域で生じた流出が下流平原地帯で消 費されているということがわかる，とりわけアムダ リア・シルダリア川周辺で損失が大きく，イリ川沿 線では純水蒸気収束量が正值をとるのに対し，アム ダリア・シルダリア川沿線の蒸発損失の影響が大き いことがわかる。蒸発散量の空間分布は純水蒸気収 束量と似通ったパターンを示す。アラル海流域グ リッドの蒸発散量は非常に高く, 下流域の平原部で 1,000mmを超えると推定された部分もある.アラル 海流域平均の年間降水量は $235.8 \mathrm{~mm}$, 推定蒸発散量 は $535.4 \mathrm{~mm}$ であり，年間の貯留量減少が $298.7 \mathrm{~mm}$ であ ると推定された。

\section{5. アラル海流域の水収支とアラル海の水量減少}

Micklin(1988)による推定では，1960～1988年の アラル海の水量減少は, 海面積の縮小を考慮すると, 年間800 830mmである(図-11)。これは，アラル海 流域全体の面積で換算すると招よそ40～45 mmに相当 する。この值は大気水収支法によって計算される流 域貯留量減少に比べて少ない. 大気水収支法自体の 推定精度の問題はあるが, 現象としてはアラル海流 域の貯留量減少は, アラル海の水量減少のみならず 周辺地域の地下水位の低下や土壤水分貯留の減少を 伴っていることを示唆していると考えられる.

前述のように, アラル海流域ではパミール高原・ テンシャン山脈で生み出された流出水を, 下流平原 部で消費するという水循環パターンがある．アラル 海流域を純水蒸気収束量の推定值から水分供給域と 損失域に分類する．両者の平均純水蒸気収束量の季
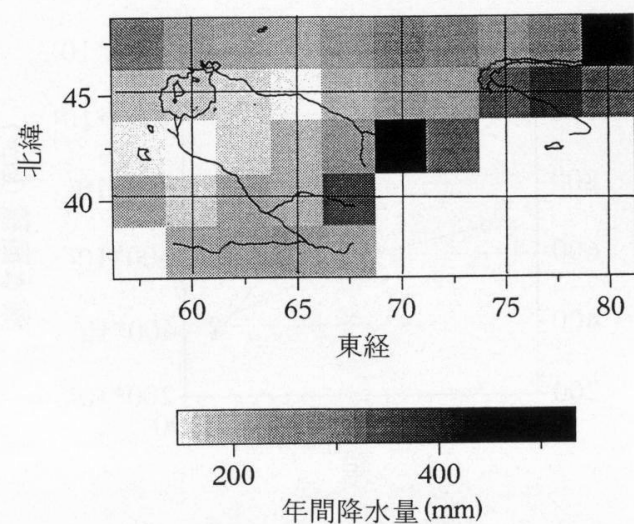

図一 8 年降水量の空間分布 (Legates and Willmott, 1990より作成)

The spatial distribution of the annual precipitation(after Legates and Willmott, 1990)
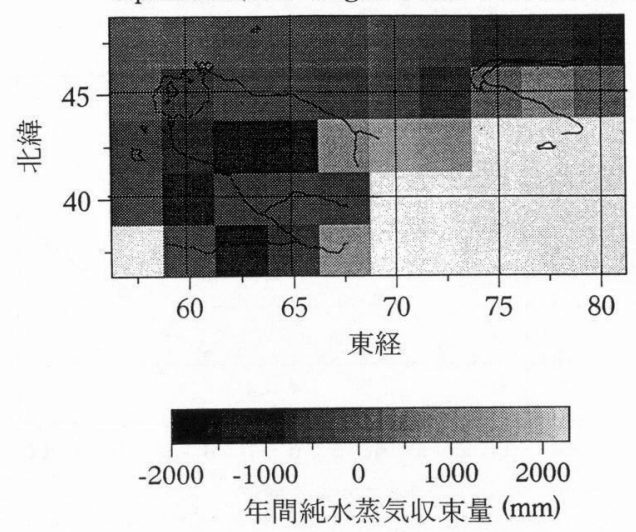

図一-9計算された年間純水蒸気収束量の空間分布 (Ohte et al., 1996)

The spatial distribution of the calculated annual net vapor flux convergence
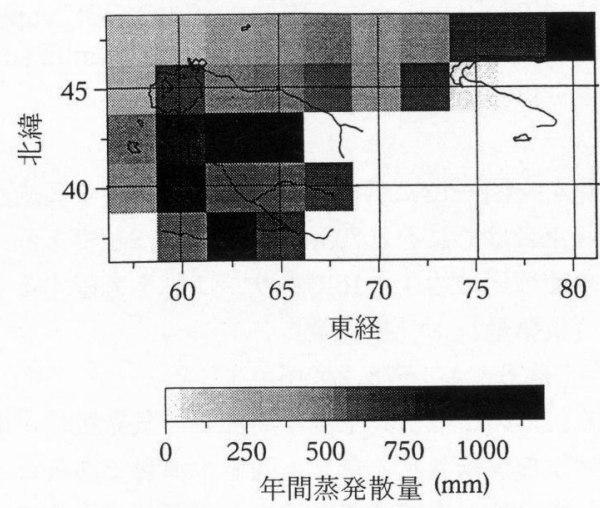

図一10 計算された年間蒸発散量の空間分布 (Ohte et al., 1996)

The spatial distribution of the calculated annual evapotranspiration 

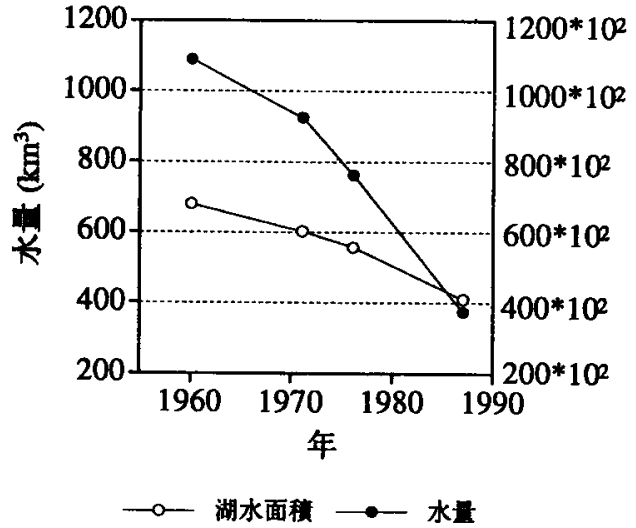

図－11 アラル海の水量墄少 (Micklin, 1998より作成) The decrease of water body of the Aral Sea (after Micklin, 1988)

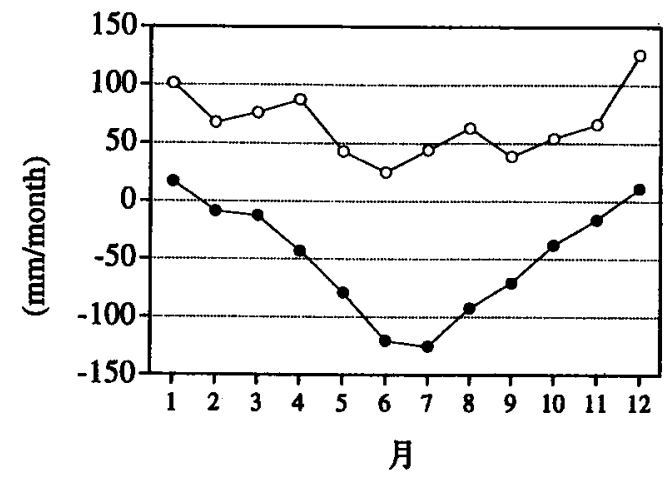

——水分損失城 ———水分供給城

図一12 水分損失域と供給域の領域平均純水蒸気収 束量の季節変動 (Ohte et al., 1996)

The seasonal changes of the net vapor flux convergence in the deficit and surplus regions

節変化をを図一12に示す，両者の領域平均年間純水 蒸気収束量はそれぞれ $793.5 \mathrm{~mm} ，-578.2 \mathrm{~mm}$ である。

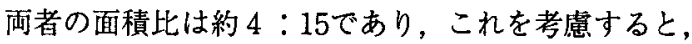

[供給量］： [損失量］

$=793.5 \times 4: 578.2 \times 15=1: 2.7$

となる。このことは，下流平原部での蒸発散量が山 岳地域から供給される量を上回る水消費であること を示しており，流域貯留の減少が平原部で生じてい ることを褰付けている。
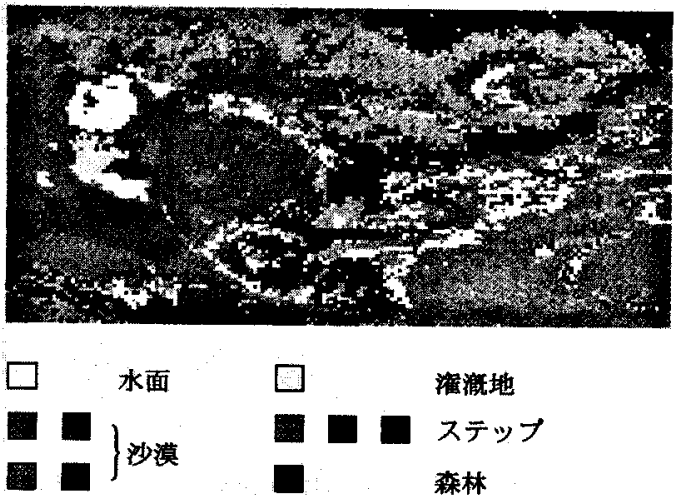

図一13 NOAA/GV画像を用いて作成した土地被 覆分類 (Ohte et al., 1996)

The land cover map from the NOAA/ GVI images

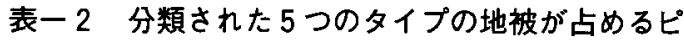
クセル数のアラル海流域のピクセル数に対 する割合(Ohte el al., 1996); Pixel frequencies of the five types of land covers of the Aral Sea basin

\begin{tabular}{lc}
\hline $\begin{array}{l}\text { Land cover type } \\
\text { 土地被覆タイフ }\end{array}$ & $\begin{array}{c}\text { Ratio of pixel number } \\
\text { ビクセル数し割合 }\end{array}$ \\
\hline Water (水面) & 0.036 \\
Desert (砂漠) & 0.652 \\
Irrigated land (潅漑地) & 0.088 \\
Steppe (ステッブ) & 0.161 \\
Forest (森林) & 0.064 \\
\hline
\end{tabular}

\section{6. 蒸発散量の空間分布と陸面状態との対応}

図一13に, NOAA/GVIデータを用いて作成した 土地被覆分類図を示し，表一 2 に，分類された水面， 砂漠, 潅溉地, ステップ, 森林の 5 つの地被につい て，アラル海流域全体に対するピクセル数の比率を 示寸．全体の65\%を沙漠が占めるが，潅激地もまた 大きな面積を占めていることがわかる．図一14は前 に分類した水分の損失域について，各グリッドに含 まれる潅溉地のピクセル数の比率とそのグリッドの 年蒸発散量との関係を示している．沙漠が大部分を 占める3つのグリッドを除く, 他のグリッドでは両 者に正の相関が見られる，年蒸発散量は当然ステッ プの面積とも相関があるものと考えられるが, 潅溉 地面積との相関は明らかである．このことは大気水 収支から求められた蒸発散量の空間分布が陸面の蒸 発散過程の影響を概ね反映していることを示してお り，特に潅溉地で蒸発散量が多いことの影響を強く 


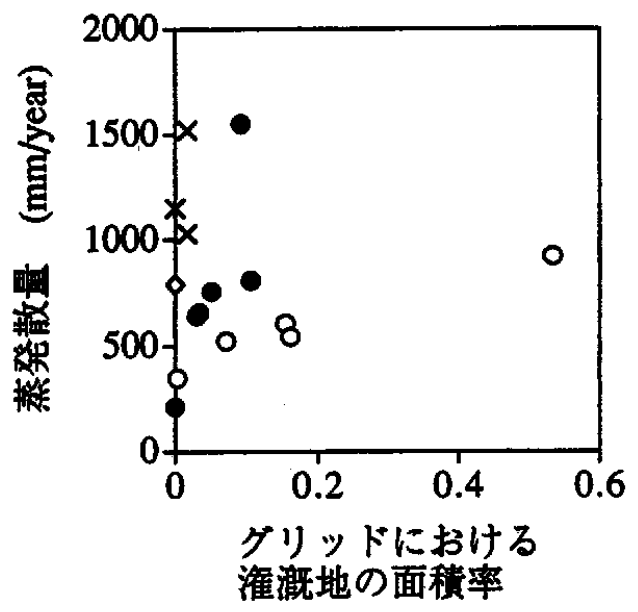

图一14 損失域解析グリッドにおける潅裤地のピク 七ル数の割合と年蒸発散贵との関係 (Ohte et al.,1996); $\bigcirc$ : 潅溉地のピクセル数が ステップより多いグリッド, ○：潅溉地の ピクセル数がステップより少ないグリッド, $\times$ : 砂漠, $\diamond:$ 大部分がアラル海のグリッ ト ; The relationship between areal ratio of the irrigated land and the annual evapotranspiration; $O:$ Grids including the irrigated land more than steppe, $O$ : Grids including the irrigated land less than steppe, $x:$ Desert, $\diamond:$ The Aral Sea grid

受けていることを物語っている。

IV.まとめ

バルハシ湖流域の潅溉農地における水・熟収支観 測から，乾燥地では植生の存在が水の消費量を堌や していること, 潅溉農地では農場開設以前の植生地 に比べて蒸発散量が大幅に増加することがわかった。 潅溉農地化に伴う蒸発散量の增加は, 水田耕作によ る湛水面積が増加したこと, 用排水路や水田からの 浸透水によって畑地の地下水位が高くなったこと， さらに導入された作物が在来種に比べて耐乾性を持 たず多くの水を消費することが原因となっていると 考えられた。

大気水収支法を用いて求めた蒸発散量の空間分布 は，アラル海流域の水循環パターンを反映したもの であり，降水量の少ない平原部での蒸発散量の多さ を浮き彫りにするものであった，潅溉農業での蒸発 散損失がこれに大きく寄与していることが植生タイ プの空間分布と対応させることで確かめられた。
本解析は，約10年前のデータをもとに行ったもの で，筒井(1998)が述べているように，1989年頃から アラル海の「回復」にむけた取り組みが徐々に始まっ ているようである。より最近のデー夕を用いた解析 を行うことによってアラル海流域の水資源上の変動 を再度検討する必要があろう。

\section{引用文塥}

福嶌義宏 (1993)：中央アジアの「水」問題ノート(そ の 1), JRAK調查報告書Na 1一中央アジア乾燥地 における大規模潅溉農業の生態環境と社会経済に 与える影響, pp. $9 \sim 19$, 日本カザフ研究会 舟川晋也・小崎隆・鈴木玲治・石田紀郎(1996)：カ ザフスタン大規模潅溉農地における土壤塩性化の 実態，農業土木学会誌，64(10)，pp. 41 45

Jury, W. A., W. R. Gardner and W. H. Gardner (1991): Soil Physics, pp. 95-99, Wiley, New York 小林達明・沖津二郎・N.P. Ogar(1994)：サクサ ウール林をはじめとしたベレケ周辺の植生の水分 動態と光合成, JRAK調查報告書№ 2 一中央アジ ア乾燥地における大規模潅溉農業の生態環境と社 会経済に与える影響, pp. 57〜 73, 日本カザフ研 究会

小杉賢一朗・福嶌義宏 (1994)：乾燥地の大規模灌溉 農場(アルファルファ畑)における蒸発散量の推定, 水文・水資源学会誌, 7(5), pp. 420 429

Kosugi, K., K. Nakajima and Y. Fukushima(1995): Estimation of evapotranspiration in both irrigated and non-irrigated lands in the arid district of Central Asia, Proc. of Symposium on the Aral Sea and Surrounding Region, pp. 92-100 小杉緑子(1995) : 気孔コンタクタンスの計測とモデ リング, 水文・水资源学会誌, 8(2), pp. 221 230

Legates, D. R. and Willmott, C. J. (1990): Mean seasonal and spatial variability in gauge-corrected precipitation. International Journal of Climatology. 10, pp. 117-127

Micklin, P. P. (1988): Desiccation of the Aral Sea: A water management disaster in the Soviet Union, Science. 241, pp. 1170-1176

Ohte, N., Oki, T. and Morimoto, Y. (1996): Large scale estimation of water budget in the Aral Sea basin by atmospheric water balance, Proc. of the Int. Conf. on Water Resour. \& Environ. Res. Vol. 
1. pp. 221-228

Oki, T., Musiake, K., Matsuyama, H. and Masuda, K. (1995): Global atmospheric water balance and runoff from large river basins, Hydrological Processes. 9, pp. 655-678

島田緑子 (1992)：光合成・蒸散過程の統合的理解に ついて (I)一光合成モデルと気孔開閉の仕組み,

日本緑化工学会誌, 17(4), pp. 32 43

竹内清秀・近藤純正 (1981) : 大気科学講座 1 地表に 近い大気, pp. 89 106, 東京大学出版会

筒井 单(1998)：乾燥地における潅较農業の進展と
環境問題：シリーズ「乾燥地の潅䘽農業と水環境」, 水文・水资源学会誌, 11(4)，pp. 398-406

渡辺紹裕 (1994)：ベレケ・ソホーズの潅溉システム と用水量, JRAK調查報告書 Na 2-中央アジア乾 燥地における大規模潅溉㖘業の生態㻴境と社会経 済に与える影響, pp. 25〜37, 日本カザフ研究会

Watanabe, T. (1995): Present problems and future prospects of paddy fields in Kazakhstan, Proc. of Symposium on the Aral Sea and Surrounding Region, pp. 123-128

（受付：1998年 8 月 2 日，受理：1998年 9 月16日） 